\title{
Ocena wiedzy pacjentów na temat czynników ryzyka związanych ze stylem życia, a występowanie chorób nowotworowych głowy i szyi
}

\section{Risk factors related to lifestyle affecting the occurrence of head and neck cancer}

\author{
URSZULA KARBOWIAK ${ }^{1}$, BOGUSŁAWA SERZYSKO 2,3 \\ 1 Studentka WSPS Dąbrowa Górnicza \\ 2 Śląskie Centrum Chorób Serca w Zabrzu, Katedra Kardiologii Wad Wrodzonych Serca \\ i Elektroterapii z Oddziałem Kardiologii Dziecięcej Śląskiego Uniwersytetu Medycznego \\ w Katowicach \\ ${ }^{3}$ WSPS Dąbrowa Górnicza
}

DOI: http://dx.doi.org/10.21784/IwP.2018.007

ISSN: 2541-1846

\section{Streszczenie:}

Wstęp. Choroba nowotworowa to złożony proces patologiczny, który rozwija się w ludzkim organizmie, który niszcząc zdrowe komórki prowadzi progresywnie do znacznych ograniczeń w funkcjonowaniu oraz znacznych dolegliwości bólowych, czasem nieustępujących po lekach przeciwbólowych. Choroba nowotworowa narządów głowy i szyi w znaczny sposób obniża jakość życia w porównaniu do populacji osób zdrowych.

Cel. Celem tego badania była ocena wiedzy pacjentów na temat czynników ryzyka związanych ze stylem życia, a występowaniem chorób nowotworowych głowy i szyi.

Materiał i metody. Badanie przeprowadzono wśród 149 pacjentów, u których rozpoznano chorobę nowotworową głowy i szyi w Przyklinicznej Przychodni Centrum Onkologii w Gliwicach za zgodą tejże palcówki. W badaniu posłużono 
się autorska ankietą zawierającą w 38 pytań. Badanie realizowano od listopada 2016r do stycznia 2017r.

Wyniki. Analiza wyników nie potwierdziła, że palenie wyrobów tytoniowych, picie alkoholu i wirus HPV są głównymi czynnikami ryzyka chorób nowotworowych głowy i szyi. Spora ilość zaznaczanych odpowiedzi to nie udzielenie odpowiedzi, co sugeruje o braku wiedzy pacjentów lub wyparcia przez nich szkodliwości w/w nałogów.

Wnioski. Badani w zdecydowanej większości byli świadomi szkodliwości palenia papierosów i jego wpływu na powstanie choroby nowotworowej. Nie mieli natomiast świadomości wpływu picia alkoholu na rozwój choroby nowotworowej. Większość badanych wiedziała, czym jest wirus HPV. Natomiast badani w większości nie mieli wiedzy, że wirus HPV należy do onkogennych. Palenie papierosów kiedykolwiek przez badanych różnicowało ich świadomość wpływu palenia papierosów na powstanie choroby nowotworowej.

Słowa kluczowe: nowotwory głowy i szyi, styl życia, jakość życia

\begin{abstract}
:
Introduction. Cancer is a complex pathological process that develops in the human body, destroying healthy cells progressively and leading to significant limitations in functioning and severe pain, sometimes persissitng even with the aid of painkillers. Cancerous diseases of the head and neck organs significantly reduce the quality of life compared to the population of healthy people.
\end{abstract}

Aim. The aim of this study was to show whether smoking, alcohol and HPV are risk factors for head and neck cancer.

Materials and methods. The study was conducted among 149 patients diagnosed with head and neck cancer in the Clinical Outpatient Center of Oncology Center in Gliwice with the consent of this heaktcare facility. The study used a questionnaire containing 38 questions. The study was carried out from November 2016 to January 2017.

Results. The analysis of the results did not confirm that smoking, alcohol and HPV are the main risk factors for head and neck cancer. A large number of respodents did not answer the questions, which suggests patients' lack of 
knowledge or their denial of the harmfulness of the above-mentioned addictions.

Conclusions. The majority of respondents were aware of the harmfulness of smoking and its effect on the development of cancer. However, they were not aware of the impact of drinking alcohol on the development of cancer. Most of the subjects knew what HPV is. However, the majority of respondents did not know that HPV belongs to oncogenic viruses. Smoking cigarettes differentiated their awareness of the impact of smoking on the development of cancer.

Keywords: head and neck cancer, lifestyle, quality of life

\section{Wstęp}

Dane literaturowe ukazują, iż nowotwory głowy i szyi obejmują raki zlokalizowane w górnej części układu pokarmowego i oddechowego (jama ustna, gardło, krtań, jama nosowa, gruczoły ślinowe i zatoki oboczne nosa). Nowotwory te różnią się historią naturalną i rokowaniem, jednak w wielu opracowaniach są ujmowane, jako jedna grupa. Szczególne znaczenie tej grupy nowotworów związane jest $\mathrm{z}$ towarzyszącymi im poważnymi dolegliwościami fizycznymi. Nowotwory umiejscowione $\mathrm{w}$ tym obszarze $\mathrm{z}$ reguły utrudniają podstawowe czynności życiowe (oddychanie, odżywianie i mowę), a niekiedy upośledzać mogą wzrok, słuch, węch, smak i inne czynności układu nerwowego. Zniekształcenia i ubytki czynnościowe w wyniku choroby i jej leczenia mają negatywne skutki psychologiczne i społeczne.

$\mathrm{Z}$ godnie $\mathrm{z}$ danymi epidemiologicznymi, nowotwory głowy i szyi stanowią 12\% wszystkich nowotworów złośliwych na świecie [1]. Liczba zachorowań na nowotwory złośliwe głowy i szyi w Polsce stanowi 9\% wszystkich rozpoznawalnych nowotworów u mężczyzn i $5 \%$ u kobiet. Występują najczęściej u osób po 45 r.ż, a raki rozwijające się, jako efekt infekcji wirusowej brodawczaka ludzkiego HPV rozpoznawane są u osób znacznie młodszych, między 15-35 r.ż., a także powyżej 50 r.ż. Niestety pond $75 \%$ tych nowotworów 
rozpoznaje się $\mathrm{w}$ zaawansowanym stadium klinicznym choroby, co prowadzi do wysokiej śmiertelności i wznowy procesu nowotworowego po radykalnym leczeniu i przerzutów odległych [2].

Najgorzej rokują pacjenci z pierwotnym ogniskiem w obrębie dna jamy ustnej i języka, gdyż już w chwili zgłoszenia się do lekarza u ponad połowy pacjentów stwierdza się przerzuty do regionalnych węzłów chłonnych [3].

Ponad 90\% wszystkich nowotworów głowy i szyi stanowią raki płaskonabłonkowe. Najczęstszą lokalizacją tego typu nowotworu jest krtań, a następnie gardło, jama ustna, warga, nos i zatoki oboczne nosa. Chorzy na ten typ nowotworu cechują się znacznie zwiększonym ryzykiem wystąpienia drugiego niezależnego nowotworu, który zwykle rozwija się $w$ drogach oddechowych lub górnym odcinku przewodu pokarmowego, dlatego niezależności te należy uwzględnić podczas badań kontrolnych po zakończeniu leczenia [4].

Wśród innych typów nowotworów głowy i szyi wyodrębniamy raka śluzowo - naskórkowego, raka niskosko zróżnicowanego drobnokomórkowego (inaczej neuroendokrynnego), nerwiaka nerwu węchowego, chłonniaki nieziarnicze oraz chorobę Hodgkina [2]. Te typy nowotworów mogą uszkadzać rdzeń kręgowy wraz z nerwami, mózg, narząd wzroku, słuchu, węchu czy mowy.

Czynniki ryzyka zwiane z rozwojem nowotworu, wywołują lub wiążą się z powodowaniem zwiększonej przydatności (wrażliwości) na różnego rodzaju zaburzenia funkcji organizmu lub wystąpienia choroby oraz obejmują czynniki wiążące się z zachowaniem, czyli z stylem życia, czynnikami biologicznymi, zagrożeniami środowiska czy społeczno - ekonomicznymi [5].

Etiologia choroby nowotworowej mimo postępu medycyny nadal pozostaje obszarem nie do końca poznanym i nadal jest drugą na świecie po chorobach układu krążenia przyczyną zgonów wśród ludzi i największym wyzwaniem zdrowia publicznego [6].

Do głównych przyczyn powstawania nowotworów głowy i szyi należą: 
- Alkohol (szczególnie wysokoprocentowy) gdzie pierwszym produktem metabolizmu alkoholu jest acetaldegyd Liczne badania dowodzą, że aldehyd octowy ma silne właściwości toksyczne, karcinogenne i mutogenne, co powoduje uszkadzanie zdrowych komórek przez wpływ na jej DNA [7], (według szacunków jedynie 5\% pacjentów z rakiem obrębu głowy i szyi to osoby niepijące, a u nałogowych alkoholików ryzyko zachorowania wzrasta nawet pięciokrotnie) $[8,9]$.

- Ekspozycja na dym nikotynowy synergistyczny efekt karcogenny - w skład dymu tytoniowego wchodzi ponad 4 tysiące substancji, z których więcej niż 40 jest znanymi związkami rakotwórczymi $[8,10,11]$. Osoby palące tytoń mają wysokie stężenie aldehydu octowego w ślinie, który może uszkadzać DNA komórek i zaburzać mechanizm jego naprawy [12].

- Zakażenie wirusem brodawczaka ludzkiego HPV dotyczy głównie części ustnej i gardła (oropharynx), w znacznie mniejszym stopniu krtani i jamy ustnej. Infekcje HPV występują średnio u 25\% chorych na nowotwory głowy i szyi, są to chorzy bez typowych czynników ryzyka takich jak palenie tytoniu i picie alkoholu, nie stwierdzono też zależności między płcią, wiekiem i wykonywana pracą zawodową [13]. Wirus zazwyczaj przenoszony jest przez kontakty seksualne, zwłaszcza u młodych osób przez seks oralno - płciowy powodując infekcje w obrębie jamy ustnej, gardła i krtani [14]. Klinicznym efektem zakażenia wirusem są brodawki skóry, błon śluzowych jamy ustnej, narządów płciowych, układu moczowego i dróg oddechowych. Wiele wirusów brodawczaka powoduje zakażenia dróg płciowych w postaci kłykcin kończystych i płaskich, które są stanami przed nowotworowymi, jak również naukowo potwierdzono korelację pomiędzy częstością raka jamy ustnej i raka szyjki 
macic. Postać powstałego schorzenia zależy w dużym stopniu od typu wirusa HPV zakażającego nabłonek $[15,16]$.

- Uwarunkowania genetyczne

- Złe nawyki żywieniowe

- Środki chemiczne w tym środki ochrony roślin oraz niektóre czynniki szkodliwe w miejscu pracy takie jak: azbest, kwas siarkowy, chrom, nikiel [17]. Niewielki odsetek zachorowań na nowotwór ucha, głowy i szyi może być związany z ekspozycją zawodową. Kurz zwiększa ryzyko wystąpienie raka jamy nosowej, a nikiel raka płaskonabłonkowego zatoki szczękowej. Produkty ropy naftowej mogą zwiększać ryzyko raka gardła.

- Zła higiena jamy ustnej i ubytki próchnicze w zębach, które sprzyjają stanom zapalnym jamy ustnej i języka [18].

- Zakażenie wirusem Epsteina - Barr (inaczej ludzki herpeswirus 4) należy do rodziny wirusów opryszczki i jest jednym $\mathrm{z}$ najczęściej spotykanych wirusów uludzi. Przypuszcza się, że wirus EBV odgrywa dużą rolę w procesie powstawania nowotworów, a także bierze udział w patogenezie depresji i zespołu przewlekłego zmęczenia.

Choroby nowotworowe narządów głowy i szyi są niewątpliwie narastającym problemem ogólno zdrowotnym, o którym mało się mówi w mediach społecznościowych. Nie poświęca się mu także zbytnio uwagi $\mathrm{w}$ badaniach przesiewowych i kontrolnych tak jak w innych nowotworach np. piersi, jelita grubego czy czerniakach. Należą do ciężkich chorób układu kostno - stawowego i tkanek miękkich połączonych zwłaszcza z występującymi przez cały czas bólami oraz towarzyszącym im zaburzeniami czucia, smaku, zmian wyglądu zewnętrznego, poczuciem osamotnienia, nieprzydatności, bezradności i lęku przed przyszłością. W znacznym stopniu wpływają na jakość życia tych osób. Złe nawyki jak palenie tytoniu od wczesnych lat i picie alkoholu według doniesień literatury przyczyniają się do tego typów występowania nowotworów. 
Głównym celem pracy była ocena wiedzy respondentów na temat wpływu czynników ryzyka na występowanie chorób nowotworowych głowy i szyi między innymi: palenie tytoniu, picie alkoholu czy zakażenie wirusem HPV.

\section{Materiał i metody}

Badanie przeprowadzono wśród 149 pacjentów w Przyklinicznej Przychodni Centrum Onkologii w Gliwicach, u których rozpoznano lub byli $\mathrm{w}$ trakcie diagnostyki $\mathrm{w}$ kierunku choroby nowotworowej obszaru głowy i szyi. Badanie realizowano od listopada 2016r do stycznia $2017 \mathrm{r}$

W celu przeprowadzenia badań skonstruowano autorski kwestionariusz ankiety, który dotyczył charakterystyki badanej grupy objętej procesem nowotworowym.

Przed przystąpieniem do analizy baza danych została sprawdzona pod względem logiczności i kompletności odpowiedzi. Braki danych w przypadku cech ilościowych zastępowano średnią, zaś w przypadku danych o charakterze porządkowym lub jakościowym odpowiednio najczęściej występującą odpowiedzią lub - jeśli była taka możliwość - odpowiedzią o treści „nie udzielam odpowiedzi”. Natomiast w dalszej kolejności, do wykonania obliczeń wykorzystany został pakiet statystyczny Statistica v.13.1 PL firmy StatSoft, Inc. 


\section{Wyniki}

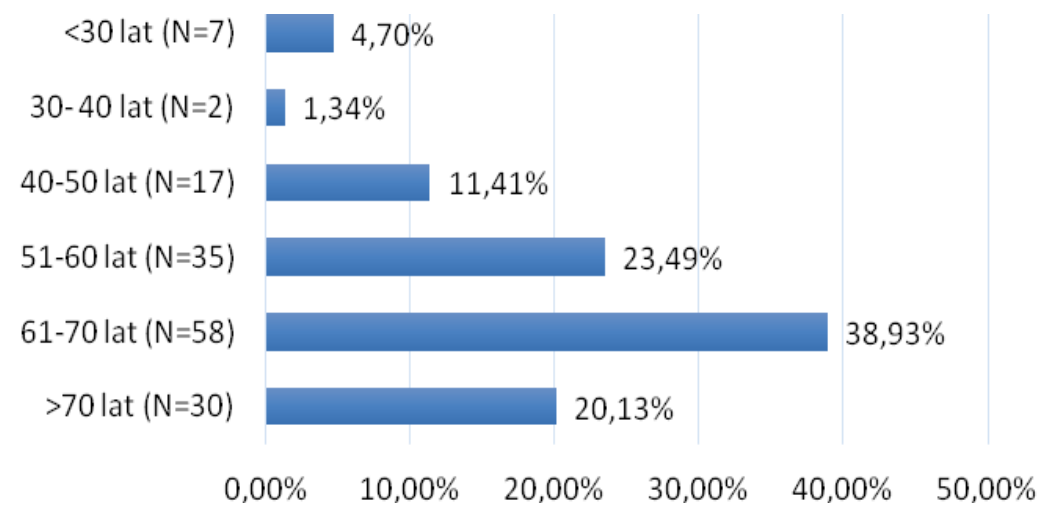

Rycina 1. Badani w podziale na wiek.

Źródło: wynik badań własnych

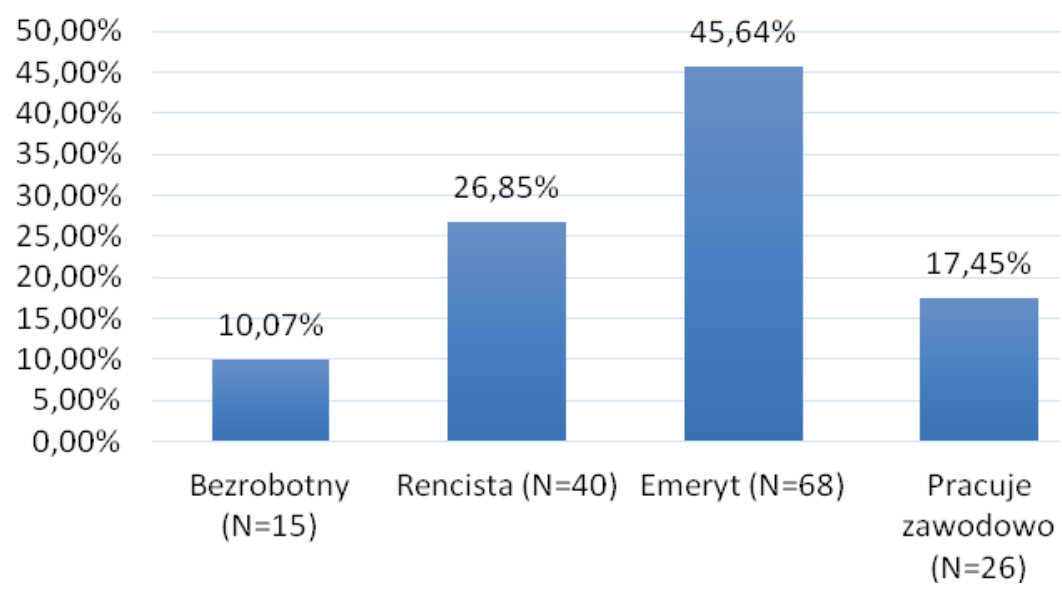

\section{Rycina 2. Badani w podziale na zatrudnienie.}

Źródło: wynik badań własnych 
Tabela 1. Liczba pobytów badanych w szpitalu w związku z obecną chorobą (podstawowe statystyki opisowe).

\begin{tabular}{|c|c|c|}
\hline \multicolumn{2}{|c|}{ Statystyki opisowe } & Liczba pobytów w szpitalu \\
\hline \multicolumn{2}{|c|}{ Średnia } & 3,70 \\
\hline \multicolumn{2}{|c|}{ Odchylenie standardowe } & 5,42 \\
\hline \multirow{2}{*}{ Poziom ufności } & $-95,00 \%$ & 2,82 \\
\hline & $95,00 \%$ & 4,57 \\
\hline \multicolumn{2}{|c|}{ Mediana } & 3,00 \\
\hline \multicolumn{2}{|c|}{ Minimum } & 0,00 \\
\hline \multicolumn{2}{|c|}{ Maksimum } & 60,00 \\
\hline \multicolumn{2}{|c|}{ Bląd standardowy } & 0,44 \\
\hline
\end{tabular}

Źródło: wynik badań własnych

Badani przebywali w szpitalu w związku $\mathrm{z}$ obecną chorobą średnio 3,70 razy, przy czym duża w stosunku do średniej wartość odchylenia standardowego $($ tj. 5,42$)$ świadczy o dużym zróżnicowaniu pod tym względem $\mathrm{w}$ obrębie badanej próby. Połowa badanych przebywała w szpitalu maksymalnie 3 razy i połowa - odpowiednio minimum 3 razy. Najmniejsze doświadczenia pod tym względem miał respondent, który nie był ani razu w szpitalu, zaś największe odpowiednio 60 razy. Zgodnie z wynikami poziomu ufności można wywnioskować, że liczba pobytów w szpitalu w związku z chorobą nowotworową u wszystkich Polaków mieści się $\mathrm{z}$ 95,00\% prawdopodobieństwem $\mathrm{w}$ przedziale między 2,82 a 4,57 razy. Z kolei, błąd standardowy średniej wynosi 0,44 , co pozwala stwierdzić, że o taką wartość średnio odbiega liczba pobytów w szpitalu w związku z chorobą nowotworową u wszystkich Polaków.

Zdecydowana większość badanych paliła kiedykolwiek w przeszłości papierosy. Blisko co czwarty respondent (24,16\%) nigdy nie palił papierosów. Natomiast aktualnie większość badanych $(58,39 \%)$ nie pali papierosów. Przy tym nałogu pozostawało 41,61\% badanych. Wśród osób palących aktualnie papierosy, większość 
badanych $(59,68 \%)$ paliła papierosy ponad 15 lat, przez okres 1 roku lub od 1 roku do 5 lat paliło odpowiednio po 12,90\% badanych. Od 5 do 10 lat paliło papierosy 8,06\% badanych, zaś od 10 do 15 lat odpowiednio $6,45 \%$. Z kolei pod względem dziennej ilości wypalanych papierosów, wśród osób palących aktualnie papierosy, większość (58,06\%) paliła 10-20 papierosów dziennie. Od 2 do 5 sztuk wypalało $14,52 \%$ badanych, zaś od 5 do 10 - odpowiednio 22,58\%. Natomiast powyżej 20 papierosów dziennie paliło 4,84\% badanych. Badani przeważnie $(41,61 \%)$ uważali, że palenie papierosów nie wpływa na powstanie choroby nowotworowej. Przeciwnego stania był niemal, co trzeci badany $(30,87 \%)$. Z kolei, $27,52 \%$ badanych nie udzieliło odpowiedzi na pytanie dotyczące powyższej kwestii. Większość badanych $(65,10 \%)$ nadal paliła papierosy mimo postawionej diagnozy choroby nowotworowej. Tylko co dziewiąta osoba $(11,41 \%)$ zaprzestała palenia. Pozostałe $23,49 \%$ badanych nie udzieliło odpowiedzi na pytanie dotyczące powyższej kwestii.

Pod względem spożywania $\mathrm{w}$ bliskich rodzinach napojów alkoholowych badani byli dość podzieleni. W przypadku 45,64\% badanych $\mathrm{w}$ ich rodzinach spożywano alkohol, zaś w przypadku niewiele mniejszej ilości badanych (tj. 43,62\%) - przeciwnie. Co dziesiąta osoba $(10,74 \%)$ nie udzieliła odpowiedzi na pytanie dotyczące powyższej kwestii. Większość badanych (53,69\%) piła napoje alkoholowe. Nie spożywała takich napojów, co trzecia badana osoba $(34,90 \%)$. Pozostałe $11,41 \%$ badanych nie udzieliło odpowiedzi na pytanie dotyczące powyższej kwestii. $\mathrm{Na}$ pytanie o rodzaj spożywanego alkoholu większość badanych $(53,02 \%)$ nie udzieliła odpowiedzi. Piwo spożywało $22,82 \%$ badanych, wódkę - odpowiednio 15,44\%, wino - odpowiednio 4,03\%, zaś inne alkohole - odpowiednio $4,70 \%$. Ponadto, na pytanie o częstotliwość spożywanego alkoholu co drugi respondent $(50,34 \%)$ nie udzielił odpowiedzi. Co czwarta osoba $(26,85 \%)$ spożywała alkohol okazjonalnie. Raz w miesiącu alkohol był spożywany przez $6,71 \%$ badanych, raz w tygodniu odpowiednio 6,04\%, co parę dni - odpowiednio 6,04\%, zaś codziennie 
alkohol piło 4,03\% badanych. Większość badanych (58,39\%) było zdania, że picie alkoholu nie wpływa na rozwój choroby nowotworowej. Przeciwnego zdania było $11,41 \%$ badanych. Natomiast niemal co trzecia osoba $(30,20 \%)$ nie udzieliła odpowiedzi na pytanie dotyczące powyższej kwestii.

Większość badanych $(53,02 \%)$ wiedziała, czym jest wirus HPV. Tej wiedzy nie posiadał, co trzeci respondent $(33,56 \%)$. Pozostałe $13,42 \%$ badanych nie udzieliło odpowiedzi na pytanie dotyczące wiedzy na ten temat. Sposób, w jaki można stać się nosicielem wirusa HPV był znany 44,97\% badanym, zaś niewiele mniej osób (ti. 40,94\%) tej wiedzy nie posiadało. Pozostałe $14,09 \%$ badanych nie udzieliło odpowiedzi na pytanie dotyczące wiedzy na ten temat. Większość badanych $(55,03 \%)$ nie wiedziała, że wirus HPV należy do onkogennych. Taką wiedzę posiadało $28,19 \%$ badanych. Pozostałe $16,78 \%$ badanych nie udzieliło odpowiedzi na pytanie dotyczące wiedzy na ten temat. Wiedzę, w jaki sposób można zarazić się wirusem posiadało $45,64 \%$ badanych. Tej wiedzy nie miał nieco mniejszy odsetek badanych (38,93\%). Pozostałe 15,44\% badanych nie udzieliło odpowiedzi na pytanie dotyczące wiedzy na ten temat. Pod względem wiedzy, czy wirus HPV jest przenoszony drogą płciową badani byli bardzo podzieleni. Taką wiedzę posiadało 37,58\% badanych, a przeciwnie - odpowiednio $30,87 \%$ badanych. Natomiast blisko co trzecia osoba $(31,54 \%)$ nie udzieliła odpowiedzi na pytanie dotyczące wiedzy na ten temat.

\section{Dyskusja}

Choroba nowotworowa jest jedną z chorób cywilizacyjnych, która przyczynia się do ograniczeń w życiu rodzinnym, zawodowym i społecznym, a ból i zmiana wyglądu w znaczny sposób obniżają jakość życia, samoocenę i zmuszają do zmniejszenia aktywności życiowej. Zastosowane leczenie operacyjne jak i zachowawcze nie zawsze gwarantuje ustąpienie dolegliwości i powrót do zdrowia, dlatego tak 
ważna jest wiedza na temat czynników wpływających na rozwój chorób nowotworowych w tym głowy i szyi głównie takich jak: palenie tytoniu, picie alkoholu czy wirus HPV.

Od lat we wszystkich dostępnych publikacjach medycznych, forach internetowych i mediach rozpowszechniony jest fakt, że palenie tytoniu jest głównym czynnikiem ryzyka w chorobach nowotworowych. Badania przeprowadzone przez Bernacką i Misiołek wykazują, że palenie ponad 20 sztuk papierosów dziennie zwiększa ryzyko raka nowotworu głowy i szyi trzynastokrotnie, a bierne palenie, czyli inhalowanie dymu nikotynowego prawie sześciokrotnie [11], co potwierdzają badania własne. Przeprowadzone badania potwierdziły, że znaczna część respondentów paliła papierosy lub była narażona w swoim środowisku na palenie bierne. W większości są świadomi szkodliwości palenia wyrobów tytoniowych, jednak nie wiążą swojego zachorowania $\mathrm{z}$ tym faktem, może, dlatego wiele $\mathrm{z}$ nich nie odpowiedziało na pytania dotyczące szkodliwości palenia, co sugerowałoby na wyparcie przez nich wiedzy i zależności nałogu z rakiem. Znaczna część ankietowanych mimo diagnozy nie zaprzestała palenia, co tłumaczy wcześniejsze przemyślenia.

Palenie wyrobów tytoniowych potęguje działanie alkoholu ułatwiając wnikanie substancji rakotwórczych zawartych w dymie wobrębie gardła i jamy ustnej. Alkohol i papierosy to często nierozłączna para, więc Ci, którzy spożywają i palą narażają się na 100 razy większe ryzyko zachorowania na nowotwory i dane takie, co rok publikuje Krajowy Rejestr Nowotworów [19]. Potwierdzają to przeprowadzone badania przez Burego i Godlewskiego [20], które jednoznacznie wykazały zależność powstawania nowotworów głowy i szyi a karcogennym działaniem alkoholu wzmacnianym paleniem. Mimo tych danych wyniki ankiety były zaskakujące. Większość respondentów (58,39\%) uważała, że picie napojów alkoholowych nie wpływa na rozwój choroby nowotworowej, być może wynika to z faktu, że osoby te nie posiadają bądź unikają świadomości szkodliwości picia i nie przyznają się do tego faktu przed samym sobą. 
Liczne badania naukowe w tym Józefowicz - Korczyńskiej i Mazeranta z I Katedry Otolaryngologii w Łodzi i Morsheda z Kliniki Onkologii Laryngologicznej Lublinie [14] pokazują, że wirus HPV zwykle jest konsekwencją określonych zachowań seksualnych takich jak kontakty ustno - płciowe, które na pewno należy potraktować, jako jeden z czynników ryzyka.

W pracy znacząca część ankietowanych $(53,02 \%)$ wykazała, że wie, czym jest wirus HPV, ale na podstawie obserwacji i dalszych wyników można wnioskować, że dane te są nieprawdziwe. Wiedza na temat onkogenności wirusa, dróg jego szerzenia i ryzyko przenoszenia się drogą płciowa, głównie poprzez seks oralny jest znikoma $(28,19 \%)$ lub ankietowani wstydzą się przyznać to takiego typu preferencji seksualnej.

Wyniki uzyskane przez Glusińskiego i Lamperską [21] stanowią o niskim udziale raków związanych z HPV w Polsce, jednak wiele wyników badań okazało się fałszywie dodatnich, dlatego wyniki wymagają uzupełnienia o bardziej precyzyjne techniki badawcze z udziałem badań PCR, czyli powielania łańcucha DNA wirusa.

Podsumowując wyniki przeprowadzonych badań własnych nie potwierdziły pośród badanej grupy, iż alkohol, tytoń czy wirus HPV byłyby głównymi czynnikami ryzyka zachorowań na raka głowy i szyi. Sprzeczna ocena odpowiedzi z licznymi, potwierdzonymi badaniami naukowymi przeprowadzonymi na całym świecie mogą wynikać z niewiedzy pacjentów, wstydu, że jest się chorym, (o czym może świadczyć bardzo duża ilość zaznaczonych odpowiedzi - nie udzielam odpowiedzi (palenie tytoniu 27,52\%, picie alkoholu 30,20\%, wiedza na temat wirusa HPV i drogami jego przenoszenia 34,23\% ) i ukrywanie nałogów. Niejednokrotnie w Instytucie badania molekularne wykrywające wirusa brodawczaka wykazały znaczy ubytek wiedzy pacjentów i co najważniejsze profilaktyki, którą powinni podjąć dla siebie jak i dla przyszłych pokoleń w celu ograniczenia szerzenia się tego typu zakażeń. 


\section{Wnioski}

- Badani w zdecydowanej większości byli świadomi szkodliwości palenia papierosów i jego wpływu na powstanie choroby nowotworowej. Nie mieli natomiast świadomości wpływu picia alkoholu na rozwój choroby nowotworowej.

- Palenie papierosów kiedykolwiek przez badanych różnicowało ich świadomość wpływu palenia papierosów na powstanie choroby nowotworowej. Osoby, które paliły kiedykolwiek papierosy znacznie częściej były świadome takiego szkodliwego wpływu tego nałogu. Natomiast palenie papierosów aktualnie nie różnicowało znacząco wiedzy w zakresie wpływu palenia papierosów na powstanie choroby nowotworowej.

- Większość badanych uważała, że picie alkoholu nie wpływa na rozwój choroby nowotworowej. Świadomość szkodliwego wpływu alkoholu pod tym katem nie była zależna od spożywania napojów alkoholowych w najbliższej rodzinie ani od picia alkoholu przez badanych.

- Większość badanych wiedziała, czym jest wirus HPV. Natomiast badani w większości nie mieli wiedzy, że wirus HPV należy do onkogennych. Wiedza na temat wirusa HPV nie była zależna od okresu trwania choroby badanych.

\section{Zalecenia dla praktyki pielęgniarskiej}

Nowotwory głowy i szyi są jednymi z sześciu najczęstszych nowotworów występujących obecnie $\mathrm{w}$ naszym kraju. Z dostępnej literatury, informacji prasowych oraz danych z Narodowego Funduszu Zdrowia wynika, że nie spotykamy się z programami profilaktyki wczesnego wykrywania tej grupy nowotworów, a według Prezesa Polskiej Grupy Badań Nowotworów Głowy i Szyi w ciągu najbliższych 20 lat częstotliwość tych nowotworów będzie znacząco wzrastać $\mathrm{z}$ malejącą tendencją występowania pozostałych nowotworów. 
Chcąc zmniejszyć ilość zachorowań, a co za tym idzie obniżać koszty leczenia trzeba położyć zdecydowanie większy nacisk na profilaktykę i badania przesiewowe [22]. Strategia ta, powinna nie tylko obejmować zadania systemu ochrony zdrowia, ale także obszary życia społecznego jak inwestycje, naukę i edukacje, które w pewnej perspektywie czasu wpływają na zwalczanie chorób nowotworowych[23]. Według dostępnej wiedzy głównymi założeniami programu powinny być:

- Ciągłe uświadamianie społeczeństwa o szkodliwości palenia wyrobów tytoniowych i picia alkoholu oraz o kancerogennych czynnikach sprzyjających rozwojowi raków w obrębie głowy i szyi.

- Szerokie zainteresowanie lekarzy pierwszego kontaktu jak i lekarzy stomatologów nałogami występującymi u ich pacjentów i informowanie o szkodliwości niektórych zachowań wpływających na stan zdrowia jamy ustnej (edukacja prozdrowotna) [24].

- Zwiększenie czujności na choroby wirusowe sprzyjające zachorowaniu na nowotwory, obserwacja i szybkie reagowanie w przypadku zmian na skórze lub/i błonach śluzowych (jama ustna, wargi, język).

- Szkolenie personelu medycznego tak, aby potrafił przekazać pacjentowi wiedzę na temat przyczyn powstawania nowotworów.

- Zwiększenie nakładów na badania profilaktyczne, wstępne i okresowe (badania krwi, badania cytologiczne, stomatologiczne itp.).

- Uświadamianie niebezpieczeństwa przypadkowych kontaktów seksualnych podczas, których można zarazić się między innymi 30 rodzajami wirusa HPV [25].

Niestety, jak wskazują badania i obserwacje dotyczące tego zagadnienia, około $1 / 3$ pacjentów wraca do nałogu palenia wyrobów tytoniowych i około $20 \%$ do picia alkoholu, natomiast nikt nie 
przyznaje się to seksu oralnego lub analnego. Dlatego należy uświadamiać populację, że zanim zdrowa komórka przemieni się w złośliwy nowotwór mijają miesiące a czasem i lata. To od nas zależy czy wykorzystamy ten czas minimalizując czynniki ryzyka chorób nowotworowych $[26,27]$.

\section{Bibliografia/Bibliography:}

1. Woźniak A. i wsp. Nowotwory głowy i szyi - historia. Przegląd Lekarski. 2012; 69 (10):1079 -1083.

2. Deptała A., Wojtukiewicz M. Z. Onkologia w praktyce lekarza rodzinnego. AsteriaMed, Gdańsk 2016.

3. Zalecenia diagnostyczno terapeutyczne dla wybranych nowotworów głowy i szyi. Postępy w Chirurgii Głowy i szyi - Suplement. 2006; 1: 36-38.

4. Kawecki A., Nawrocki S. Nowotwory nabłonkowe narządów głowy i szyi. W: Krzakowski M., Warzocha K. (Red.) Zalecenia postępowania diagnostyczno-terapeutycznego $\mathrm{w}$ nowotworach złośliwych. VM Media, Gdańsk 2013: 2-32.

5. Wojtczak A. Zdrowie publiczne: wyzwania dla systemów zdrowia XXI wieku. Wydawnictwo Lekarskie PZWL, Warszawa 2009.

6. Fol M., Jachowicz E. Czynniki zakaźne w procesie nowotworzenia. Medycyna Ogólna i Nauki o Zdrowiu. 2016; 22 (1): 7-14.

7. Plagens-Rotman K. Czynniki ryzyka zachorowania na nowotwory złośliwe narządu rodnego u kobiet. Rozprawa doktorska, UM w Poznaniu, Poznań 2014: 28.

8. Bury P., Godlewski D, Wojtyś P. Alkohol, jako czynnik ryzyka choroby nowotworowej. Współczesna Onkologia 2000; 1: 13-15. 
9. Śledź J. Nowotwory jamy ustnej - dane epidemiologiczne i czynniki ryzyka zachorowania. Biuletyn Wydziału Farmaceutycznego Warszawskiego Uniwersytetu Medycznego. 2015; 2: 6-12.

10. Kawecki A. Nowotwory narządów głowy i szyi. W: Meder J. (Red.) Aktualne zasady postępowania diagnostyczno terapeutycznego w onkologii. CMKP, Warszawa 2011: 5-20.

11. Tuchowska P.: Najczęstsze nowotwory złośliwe w Polsce - główne czynniki ryzyka i możliwości optymalizacji działań profilaktycznych: Probl Hig Epidemiol 2013,94(2): 166-171.

12. Stefanowicz A. Nowotwory złośliwe. W: Kulik B. T. Zdrowie publiczne. Wyd. Lekarskie PZWL, Warszawa 2014.

13. Józefowicz- Korczyńska M. i wsp. Wczesna ocena zależności pomiędzy zakażeniem Human papilota virus (HPV) a wybranymi cechami nowotworu u chorych na raka krtani. Otolaryngologia. 2014,13(3): 155-162.

14. Morshed K. Udział wirusa brodawczaka ludzkiego HPV w etiopatogenezie nowotworów głowy i szyi: Otolaryngologia. 2004,3(3): 91-96.

15. Broniarczyk J. i wsp. Biotechnologia - struktura i właściwości wirusa brodawczaka ludzkiego. Biotechnologia. 2010; 3 (90):126-145.

16. Więcławska M. i wsp. Zakażenie wirusem brodawczaka ludzkiego (HPV) w obrębie jamy ustnej i gardła. Czas. Stomat. 2005; LVIII,10:689-702.

17. Bernacka K. i wsp.: Carcinoma of the larynx and the hypopharynx. Rak krtani i krtaniowej części gardła. Problemy Medycyny Rodzinnej. 2012; 3 (39):56-63.

18. http://publicznecentraonkologii.pl/pacjent/rak-jezyka-prof-zw-drhab-med-alina-morawiec-sztandera-wojewodzki-szpital- 
specjalistyczny-im-m-kopernika-w-lodzi/ Dostęp: 29.10.2016 godz.21.10.

19. Polska Agencja Prasowa. Rynek aptek. http://www.rynekaptek.pl/drukuj/14472.html Dostęp: 14.06.2016r. godz.14.22.

20. Bury P., Godlewski D., Wojtyś P.: Alkohol jako czynnik ryzyka choroby nowotworowej. Współczesna Onkologia. 2000;1;13-15.

21. Golusiński P. i wsp. Występowanie i rola aktywnej infekcji wirusem brodawczaka ludzkiego (HPV) w rakach płaskonabłonkowych głowy i szyi. Polski Przegląd Otolaryngologiczny. 2012; 1(3): 244-251.

22. http://whc.ifps.org.pl/wpcontent/uploads/2013/04/informacja_pr asowa_2013_rok_walki_z_nowotworami_glowy_i_szyi.pdf Dostęp: 20.01.2017r godz.23.30.

23. Kozierkiewicz A., Jassem J.: Narodowe strategie zwalczania nowotworów: doświadczenia, struktura, dobre praktyki. Nowotwory. 2013; 63: 368-374.

24. Raczkowska -Siostrzonek A., Koszowski R.: Wpływ wizyt u lekarza stomatologa na poziom wiedzy o chorobie nowotworowej jamy ustnej. Dent. Med.Probl.2005;42,4:555-560.

25. Golusiński W. i wsp. Ogólnopolski Program Profilaktyki i Wczesnego Wykrywania Nowotworów Głowy i Szyi. Otolaryngologia Polska. $2015 ; 69,4: 7-12$.

26. De Walden - Gałuszko K.: Psychoonkologia w praktyce klinicznej. Wydawnictwo Lekarskie PZWL, Warszawa 2011:73.

27. Wrotek K. Profilaktyka antyrakowa. Wydawnictwo Helion, Gliwice 2010: 11. 